\title{
Influenza virus NS1 protein binds cellular DNA to block transcription of antiviral genes
}

\section{Anastasina, Maria}

2016-11

Anastasina , M , Le May , N, Bugai , A , Fu , Y , Soderholm , S , Gaelings , L, Ohman , T , Tynell , J , Kyttanen , S , Barboric , M , Nyman , T A , Matikainen, S , Julkunen , I, Butcher , S J , Egly , J-M \& Kainov, D E 2016, ' Influenza virus NS1 protein binds cellular DNA to block transcription of antiviral genes ' , Biochimica et Biophysica Acta. Gene Regulatory Mechanisms , vol. 1859 , no. 11 , pp. 1440-1448 . https://doi.org/10.1016/j.bbagrm.2016.09.005

http://hdl.handle.net/10138/229281

https://doi.org/10.1016/j.bbagrm.2016.09.005

publishedVersion

Downloaded from Helda, University of Helsinki institutional repository.

This is an electronic reprint of the original article.

This reprint may differ from the original in pagination and typographic detail.

Please cite the original version. 


\section{Influenza virus NS1 protein binds cellular DNA to block transcription of antiviral genes}

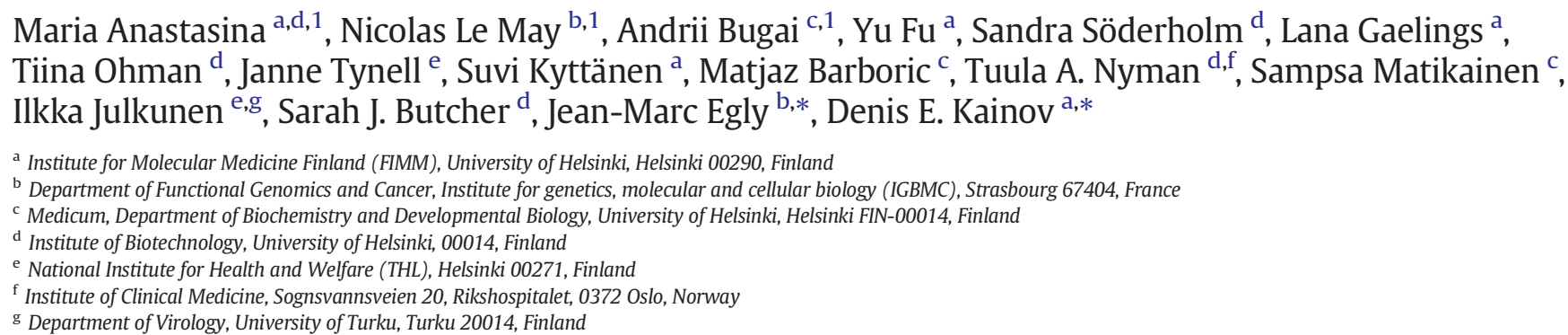

${ }^{\mathrm{b}}$ Department of Functional Genomics and Cancer, Institute for genetics, molecular and cellular biology (IGBMC), Strasbourg 67404, France

c Medicum, Department of Biochemistry and Developmental Biology, University of Helsinki, Helsinki FIN-00014, Finland

d Institute of Biotechnology, University of Helsinki, 00014, Finland

e National Institute for Health and Welfare (THL), Helsinki 00271, Finland

${ }^{\mathrm{f}}$ Institute of Clinical Medicine, Sognsvannsveien 20, Rikshospitalet, 0372 Oslo, Norway

${ }^{g}$ Department of Virology, University of Turku, Turku 20014, Finland

\section{A R T I C L E I N F O}

\section{Article history:}

Received 21 July 2016

Received in revised form 26 August 2016

Accepted 19 September 2016

Available online 21 September 2016

\section{Keywords:}

Regulation of gene expression

Influenza A virus

Innate immunity

Antiviral responses

Viral counter-responses

\begin{abstract}
A B S T R A C T
Influenza NS1 protein is an important virulence factor that is capable of binding double-stranded (ds) RNA and inhibiting dsRNA-mediated host innate immune responses. Here we show that NS1 can also bind cellular dsDNA. This interaction prevents loading of transcriptional machinery to the DNA, thereby attenuating IAVmediated expression of antiviral genes. Thus, we identified a previously undescribed strategy, by which RNA virus inhibits cellular transcription to escape antiviral response and secure its replication.
\end{abstract}

(C) 2016 Elsevier B.V. All rights reserved.

\section{Introduction}

Influenza A viruses (IAVs) are important human pathogens that cause global epidemics and pandemics (www.who.int). It is estimated that IAVs are responsible for up to 500,000 deaths a year [1]. The successful recovery from viral infection largely depends on efficient activation of innate and adaptive immune responses [2-4]. Innate immune responses are triggered by cellular Toll-like receptors (TLR3 and TLR7), which recognize viral patterns upon IAV entry in the cell [4-6]. These pattern recognition receptors (PRRs) activate transcription of interferon genes (IFNB1, IL28A, IL29, IL28B, IFNG, IFNA1, IFNA2, and IFNW1), whose products mediate expression of interferon stimulated genes (ISGs) [7-10]. Following transcription of ISGs, their protein products, such as RIG-I (DDX58), MDA5 (IFIH1), and PKR (EIF2AK2) recognize viral RNA and its replication intermediates to trigger activation of innate immune responses and apoptosis, as well as to inhibit protein synthesis [11-13]. In addition, the ribonucleases encoded by other ISGs (OASL, OAS1, ISG20) degrade viral RNA [14-16]. Moreover, E3-ligases and

\footnotetext{
* Corresponding authors.

E-mail addresses: egly@igbmc.fr (J.-M. Egly), denis.kainov@helsinki.fi (D.E. Kainov).

1 These authors contributed equally.
}

ubiquitin-like molecules encoded by HERC5, Trim25, and ISG15 ISGs modify influenza and cellular proteins to alter their cellular functions $[17,18]$. Simultaneously, cytokines produced from IL1B, IL8, IL6, CXCL10, CCL5 and some other ISGs are secreted from infected cells to alarm bystander uninfected cells of a viral infection as well as to attract immune cells to the site of infection $[2,4,19]$. Some of these cytokines are processed into secretory forms by the inflammasome, which is activated by IFN-inducible GTPases, such as GBP1, GBP4, GBP5, MX1 and MX2 [20-22]. Moreover, COX2, IDO and 25HC encoded by PTGS2, IDO, and $\mathrm{CH} 25 \mathrm{H}$ ISGs catalyse the production of prostaglandin $\mathrm{H} 2$, kynurenine, and oxysterol 25-hydroxycholesterol, respectively, which act as immuno- and neuromediators [19,23-25]. Thus, antiviral response consist of transcriptional, post-transcriptional, translational and post-translational events resulting in the clearance of infection.

To counteract the cellular defence and secure viral replication, IAV utilizes its non-structural NS1 protein, which is synthesized by infected cells only few hours after infection. NS1 interacts with replication intermediates of viral RNA to hinder these molecules from recognition by cellular PRRs [26]. It also binds RIGI, PKR, TRIM25, ISG15, GBP1 and other ISG products, to inhibit their functions $[27,28]$. However, NS1 interactions with these host antiviral proteins are virus- or host cellspecific [27-30]. We hypothesized that NS1 could also block the 
transcription of innate antiviral genes by binding cellular DNA to prevent the loading of cellular transcriptional machinery (Fig. 1A and B). Indeed, we demonstrate that NS1 binds cellular dsDNA, antagonizes RNA polymerase II (Pol II) recruitment to the DNA and, consequently, inhibits the transcription of IFNs and ISGs. Thus, our study offers a previously undescribed mechanism, by which RNA virus manipulates cellular transcription to downregulate the antiviral responses.

\section{Materials and methods}

\subsection{Viruses and cells}

Influenza A/WSN/33(H1N1) viruses expressing wild type ( $\mathrm{WSN}^{\mathrm{WT}}$ ) or R38A/K41A mutant NS1 (WSN ${ }^{\mathrm{RK} / \mathrm{AA}}$ ) were generated using WSN eight-plasmid-based reverse genetics system in HEK and Vero cells as described previously [31]. We sequenced the viral NS1 genes of $\mathrm{WSN}^{\mathrm{RK} / \mathrm{AA}}$ and $\mathrm{WSN}{ }^{\mathrm{WT}}$ viruses to verify the authenticity of the mutations. Viruses were titrated in Madin-Darby canine kidney epithelial (MDCK) cells using plaque assay as described [32]. We obtained smaller plaques and approximately 100 times lower titres for $\mathrm{WSN}^{\mathrm{RK} / \mathrm{AA}}$ virus than for WSN ${ }^{\mathrm{WT}}$ (Fig. S1). The viruses were stored at $-80^{\circ} \mathrm{C}$.

MDCK, human embryonic epithelial cells (HEK293T) and African green monkey kidney epithelial cells (Vero) were grown in Dulbecco modified Eagle's medium (DMEM; Sigma-Aldrich, St. Louis, MO, USA) supplemented with $2 \mathrm{mM}$ L-glutamine (Lonza; Basel, Switzerland), $50 \mathrm{U} / \mathrm{ml}$ penicillin-streptomycin mix (PenStrep, Lonza) and $10 \%$ fetal bovine serum (FBS; Gibco, Paisley, UK). Human telomerase reverse transcriptase-immortalized retinal pigment (RPE) cells were grown in DMEM-F12 medium supplemented with $50 \mathrm{U} / \mathrm{ml}$ PenStrep, 2 mM L-glutamine, $10 \%$ FBS, and $0,25 \%$ sodium bicarbonate (Sigma-Aldrich). The cells were propagated at $37{ }^{\circ} \mathrm{C}$ in $5 \% \mathrm{CO}_{2}$.

\subsection{Transfection of RPE cells with siRNA}

RPE cells were cultured to $80 \%$ confluency in 24 well plates and transfected with $100 \mathrm{nM}$ siGenome SMARTpool or ON-TARGETplus non-targeting control siRNA (Table S1; Dharmacon, Lafayette, CO, USA) using Lipofectamine ${ }^{\circledR}$ RNAiMAX Reagent (Thermo Fisher Scientific). Importantly, some of these siRNA have been validated in previous $[33,34]$ and in the present study (Fig. S2). $24 \mathrm{~h}$ after transfections, the cells were infected with WSN ${ }^{\mathrm{WT}}$, WSN ${ }^{\mathrm{RK} / \mathrm{AA}}$ viruses or mock infected. $8 \mathrm{~h}$ after infection, the levels of genes and proteins of interest were analysed using RT-qPCRs and immunoblotting, respectively.

\subsection{Infection of RPE cells with WSN ${ }^{W T}$ and $W S N^{R K / A A}$ viruses}

The growth medium of RPE cells was changed to the virus growth medium (VGM) containing 0.2\% BSA (Sigma-Aldrich), 2 mM L-gluta-

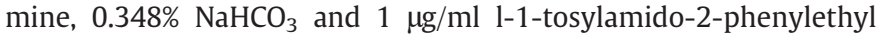
chloromethyl ketone-trypsin (TPCK)-trypsin (Sigma-Aldrich) in DMEM-F12. The cells were infected with WSN ${ }^{\mathrm{WT}}$, WSN ${ }^{\mathrm{RK} / \mathrm{AA}}$ viruses or mock.

\subsection{Gene expression profiling}

RNA was extracted from WSN ${ }^{\text {WT }}$-, WSN ${ }^{\mathrm{RK} / \mathrm{AA}}$ - or mock-infected RPE cells at 8 h.p.i. using RNeasy Plus mini kit (Qiagen, Germany). Gene expression profiling was done using Illumina Human HT-12 v4 Expression BeadChip Kit according to manufacturer's recommendation as described previously [35]. Raw microarray data were normalized using the BeadArray and Limma packages from Bioconductor suite for R. Normalized data were further processed using a variance and intensity filter. Genes differentially expressed between samples and controls were determined using the Limma package. Benjamini-Hocberg multiple testing correction testing method was used to filter out differentially expressed genes based on a q-value threshold $(\mathrm{q}<0.05)$. Filtered data were sorted by logarithmic fold change $\left(\log _{2} \mathrm{Fc}\right)$. The gene-expression data was deposited to Gene Expression Omnibus (GEO accessory number: GSE65699). Gene set enrichment analysis was performed using open-source software (www.broadinstitute.org/gsea).

\subsection{Quantitative PCR}

Quantitative PCRs were done on the Lightcycler 480 using Fast SYBR Green Master Mix (Roche, USA). The following sets of primers were used for detection of specific genes or cDNA: EML4 (forward: $5^{\prime}$-TGGC TTCAGTGCAACTCTT-3', reverse: 5'-AATCTCCATCACTGCCCATC-3'), IFNB1 promotor (forward: 5'-GTCAGTAGAATCCACGGATACAG-3' and reverse: 5'-CTTGGGAGAAAGCAAAGGAAAG-3') and exon (forward: 5'GCCGCATTGACCATCTATGA-3' and reverse: 5'-GCCAGGAGGTTCTCAA CAATAG-3'), IFNA1 (forward: 5'-ATGGCAACCAGTTCCAGAAG-3', reverse: 5'-CATCCCAAGCAGCAGATGAA-3'), IFNA16 (forward: 5'-GACT CACTTCTATAACCACCACAA-3', reverse: 5'-TAGTGCCTGCACAGGTAAAC3'), IL6 (forward: 5'-TCATCACTGGTCTTTTGG-3', reverse: 5'-CTCTGG CTTGTTCCTCAC-3'), CXCL1 (forward: 5'-TGAGCATCGCTTAGGAGA-3', reverse: 5'-AGGACAGTGTGCAGGTAG-3'), and IL29 (forward: 5'-AGGC TGAGCTGGCCCTGA-3', reverse: 5'-GGTGTGAAGGGGCTGGTC-3'). The relative gene expression differences were calculated as described
A

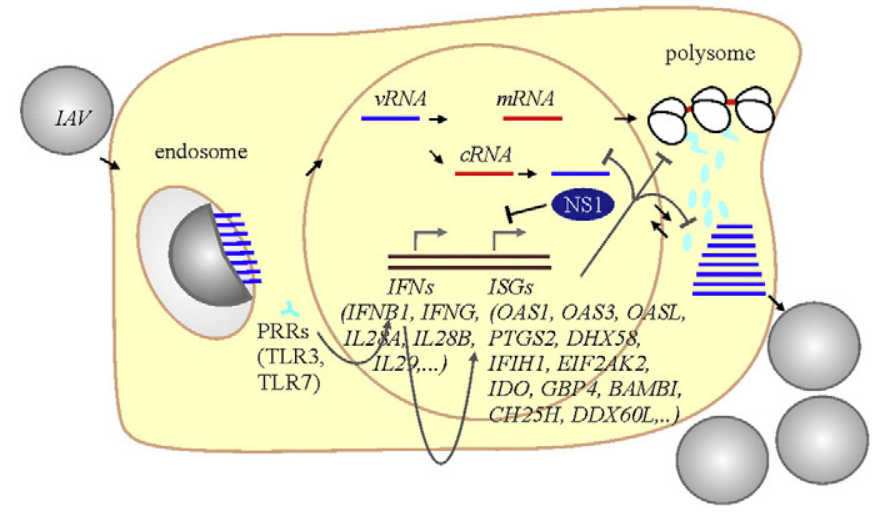

B

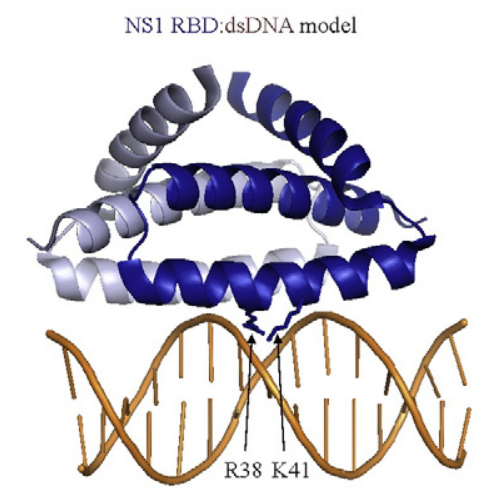

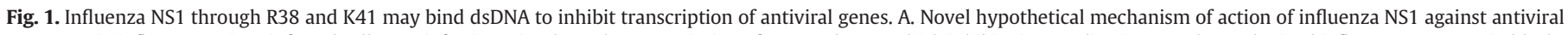

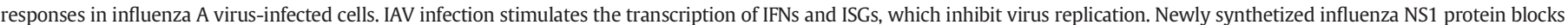

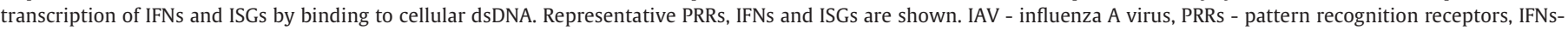

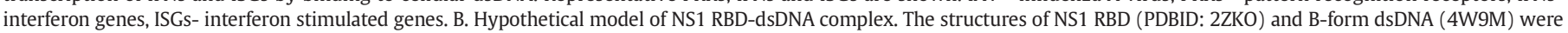
used to build this model. 
previously [36] and the results were represented as relative units (RU). Technical triplicates of each sample were performed on the same qPCR plate and non-templates and non-reverse transcriptase samples were analysed as negative controls. Statistical significance $(p<0.05)$ of the quantitation results was evaluated with $t$-test. Benjamini-Hochberg method was used to adjust the $p$-values.

\subsection{Immuno-fluorescence analysis (IFA)}

RPE cells were infected with WSN ${ }^{\mathrm{WT}}$ (moi 1) or WSN ${ }^{\mathrm{RK} / \mathrm{AA}}$ (moi 1) viruses or they were mock-infected. After $10 \mathrm{~h}$ of infection the cells were fixed with $4 \%$ paraformaldehyde (PFA) in phosphate buffered saline (PBS), then permeabilized and blocked in the BP buffer (10\% Bovine serum albumin (BSA) and $0.1 \%$ Triton X-100 in PBS) supplemented with $5 \%$ goat serum (Life Technologies, USA). Primary rabbit anti-NS1 antibodies (32) were added followed by secondary goat anti-rabbit antibodies with an Alexa488 fluorophore (Life Technologies, USA) in BP buffer, nuclei were counterstained with DAPI, and the slides were mounted with Prolong Gold anti-fade reagent (Life Technologies, USA). Images were captured with Nikon 90i microscope and processed with NIS elements AR software.

\subsection{Chromatin immunoprecipitation}

ChIP experiments were performed on RPE cells infected with $\mathrm{WSN}^{\mathrm{WT}}$ (moi 1), WSN ${ }^{\mathrm{RK} / \mathrm{AA}}$ (moi 1) or mock as previously described (34). Briefly, after cross-linking with formaldehyde at room temperature, chromatin was prepared, sonicated on ice using Bioruptor (Diagenode, Philadelphia, PA, USA) and pre-cleared. Samples were incubated with the antibody and then pulled down using protein G Sepharose beads. After extensive washes the protein-DNA complexes were eluted, the cross-linking was heat-reverted. DNA was purified with QIAquick PCR purification kit (Qiagen) and quantified by PCR with primers targeting promotor or exon region of IFNB1 gene was performed.

\subsection{Protein electrophoresis and immunoblotting}

Cells were lysed with a $2 \times$ Laemmli loading buffer ( $4 \%$ sodium dodecyl sulphate, 20\% glycerol, 10\% 2-mercaptoethanol, 0.004\% bromphenol blue and $0.125 \mathrm{M}$ Tris HCl, pH 6.8). Proteins were resolved in 4-20\% gradient SDS-polyacrylamide gel (Biorad, Hercules, USA) at $150 \mathrm{~V}$ for $50 \mathrm{~min}$. The gels were stained using Coomassie blue or immunoblotted. For immunoblotting, proteins were transferred from SDS-PAGE onto Immobilon-P membranes (Millipore, MA, USA). The membranes were blocked with $5 \%$ non-fat milk or 5\% BSA (Sigma-Aldrich) in TBST, stained with different primary antibodies overnight, followed by secondary HRP-conjugated antibody labelling and detection by chemiluminescence. The primary antibodies used in this study were anti-RNA polymerase II CTD repeat YSPTSPS antibody (1:1000 dilution in 5\% BSA-TBST; Abcam, 8WG16), goat anti-TLR3 (1:1000 dilution in 5\% BSA-TBST; sc8692, SantaCruz), rabbit anti-MAVS (1:1000 dilution in 5\% BSA-TBST; from I. J. laboratory), guinea pig anti-MDA5 (1:250 dilution in 5\% milk-TBST; from I. J. laboratory), and rabbit anti-IAV NS1 antibody (1:5000 dilution in 5\% BSA-TBST; from I. J. laboratory). The secondary HRP antibodies (anti-guinea pig, anti-goat and antirabbit) were from Dako and used as 1:1000 dilution. To confirm equal sample loading the membranes were stripped and labelled with antiGAPDH antibody (1:1000 dilution in 5\% milk-PBST, Santa Cruz, sc47724).

\subsection{Enzyme-linked immunosorbent assay (ELISA)}

The levels of CXCL10, TNF $\alpha$, and IFN $\lambda$ in the cell supernatants were assayed with ELISA (PBL Interferon Source) as described previously [37].

\subsection{Mass spectrometry}

Five $175 \mathrm{~cm}^{2}$ plates of RPE cells were infected with WSN ${ }^{\mathrm{WT}}$ (moi 1 ) or $\mathrm{WSN}^{\mathrm{RK} / \mathrm{AA}}$ (moi 3) viruses or were left mock-infected. $10 \mathrm{~h}$ post infection the media was removed. $400 \mu$ of lysis buffer $(20 \mathrm{mM}$ Tris- $\mathrm{HCl}$, $\mathrm{pH} 7.5,100 \mathrm{mM} \mathrm{NaCl}$ and $1 \%$ Tryton-X100) was added to each plate. The lysates were collected and centrifuged at $14,000 \mathrm{rpm}$ at $4 \mathrm{C}$ for $10 \mathrm{~min}$. Insoluble fractions were resuspended in $2 \mathrm{ml}$ buffer containing $20 \mathrm{mM}$ Tris- $\mathrm{HCl}, \mathrm{pH} 7.5,100 \mathrm{mM} \mathrm{NaCl}$ and $0.1 \mathrm{mg} / \mathrm{ml}$ RNAse A (Qiagene) and incubated on ice for $1 \mathrm{~h}$. The mixtures were centrifuged at 14,000 rpm at $4 \mathrm{C}$ for $10 \mathrm{~min}$. Insoluble fractions were resuspended in $2 \mathrm{ml}$ lyses buffer and centrifuged again to remove remaining RNAse and cleaved RNA. Insoluble fractions were resuspended in $2 \mathrm{ml}$ buffer containing $20 \mathrm{mM}$ Tris-HCl, pH 7.5 and $600 \mathrm{mM} \mathrm{NaCl}$. Insoluble fractions were obtained by centrifugation, resuspended in $2 \mathrm{ml}$ buffer containing $20 \mathrm{mM}$ Tris- $\mathrm{HCl}, \mathrm{pH} 7.5$ and $100 \mathrm{mM} \mathrm{NaCl}$ and sonicated for $20 \mathrm{~min}$ (2 s pulse/ $2 \mathrm{~s}$ pause; amplitude $25 \%, 20 \mathrm{kHz}, 750 \mathrm{~W}$ ). Proteins were resolved on SDS page.

Identification and quantification of proteins of "insoluble fraction" was done using quadri-plex iTRAQ (isobaric tag for relative and absolute quantitation) labelling combined with liquid chromatography-tandem mass spectrometry (LC-MS/MS) analysis as described previously [38]. In brief, protein alkylation, trypsin digestion and labelling of the resulting peptides were done according to manufacturer's instructions (AB Sciex). Labelled peptides were fractionated by strong cation exchange chromatography and each fraction containing labelled peptides was analysed twice with nano-LC-ESI-MS/MS using Ultimate 3000 nano-LC (Dionex) and QSTAR Elite hybrid quadrupole time-of-flightMS (AB Sciex). MS data were acquired automatically using Analyst QS 2.0 software. Protein identification and relative quantitation was performed using ProteinPilot 4.0 software (AB Sciex). Data files from both technical replicates of an iTRAQ sample set were processed together. The search database was a self-built combination of Uniprot Human protein sequences and Uniprot ssRNA negative-strand virus sequences (both form the release 55.0, 02/08). The search criteria were: cysteine alkylation with MMTS, trypsin digestion, biological modifications allowed, thorough search and detected protein threshold of 95\% confidence (Unused ProtScore $>1.3$ ). Additionally, automatic bias correction was used. False discovery rates were calculated using a concatenated normal and reversed sequence database.

\subsection{In vitro assays}

Wild type (NS1 $1^{\mathrm{WT}}$ ) and R38A, K41A mutant ( $\left.\mathrm{NS}^{\mathrm{RK} / \mathrm{AA}}\right)$ of NS1 of influenza A/chicken/Nigeria/OG10/2007(H5N1) virus were produced in E. coli BL21(DE3) cells and purified to homogeneity as described previously [39]. Importantly, we also attempted but did not succeed to purify wild type proteins of A/WSN/1933, A/Udorn/1972, and many other IAV strains because they were insoluble when overexpressed in E. coli BL21(DE3) cells.

Run-off transcription assay was performed using highly-purified TFIIB, TFIIE, TFIIF, TFIIH, TBP, RNA polymerase II and NS1 ${ }^{\text {WT }}$ or NS1 ${ }^{\text {RK/AA }}$ protein as described previously [40].

EMSA assay was performed with recombinant purified NS1 ${ }^{\mathrm{WT}}$ or $\mathrm{NS} 1^{\mathrm{RK} / \mathrm{AA}}$ proteins and dsDNA fragments as described previously [41]. Briefly, the synthetic 199 bp-long dsDNA (DNA-199) was produced by PCR using two oligonucleotides (forward 5'-ATGGATCCAAACACTGTGT CA-3', reverse 5'-CTCCACTATTTGCTTTCCA-3') and pHW188-NS plasmid as a template (29). The synthetic 76 bp-long dsDNA (DNA-SELEX) was produced as described in [42]. Hundred ng of dsDNA was incubated with purified recombinant proteins for $15 \mathrm{~min}$ on ice. $10 \times$ loading buffer ( $20 \mathrm{mM}$ Tris- $\mathrm{HCl} \mathrm{pH} \mathrm{8.6,50} \mathrm{mM} \mathrm{NaCl,} \mathrm{10 \%} \mathrm{glycerol)} \mathrm{was} \mathrm{added} \mathrm{to} \mathrm{the}$ samples and the samples were resolved in $1 \%$ agarose gel containing ethidium bromide in a TAE buffer ( $40 \mathrm{mM}$ Tris-base, $20 \mathrm{mM}$ acetic acid, $1 \mathrm{mM}$ EDTA). Protein-DNA-SELEX complex were excised from the gel, and DNA was purified using Qiaquick gene extraction kit 
(Qiagen). The DNA was sequenced with SR3 primer (5'-GTTCAGAGTTC TACAGTC-3') using ABI3730xl DNA Analyzer and standard Sanger method, adjusted for sequencing of short fragments.

Microscale thermophoresis assay was performed with recombinant highly-purified NS1 ${ }^{\mathrm{WT}}$ or $\mathrm{NS} 1^{\mathrm{RK} / \mathrm{AA}}$ proteins and fluorescently labeled synthetic 199 bp-long dsDNA (DNA-199). DNA-199 was produced by PCR using oligonucleotides containing a cyanine fluorophore covalently linked to the $5^{\prime}$ ends and pHW188-NS plasmid as a template. $10 \mathrm{pM}$ of Cy5-labeled synthetic dsDNA was incubated with different concentrations of purified proteins for 5 min on ice. Differences in thermophoretic properties of free and protein-bound dsDNA were determined using Monolith NT.115 instrument (NanoTemper Technologies, Munich, Germany).

\section{Results}

\subsection{NS1 inhibits transcription of antiviral genes in virus-infected cells}

It has been previously shown that NS1 through R38 and K41 residues binds dsRNA to sequester it from recognition by PRRs [15,43, 44]. We hypothesized that via the same residues, NS1 could also bind dsDNA to inhibit transcription of IFNs and ISGs (Fig. 1B). To test this hypothesis, we used wild-type influenza A/WSN/33(H1N1) virus $\left(\mathrm{WSN}^{\mathrm{WT}}\right.$ ) and its variant (WSN ${ }^{\mathrm{RK} / \mathrm{AA}}$ ), which expresses NS1 protein with R38A and K31A [31]. We infected human RPE cells with WSN ${ }^{\text {WT }}$ or WSN ${ }^{\mathrm{RK} / \mathrm{AA}}$ viruses, and used the uninfected cells (mock) as a control. $8 \mathrm{~h}$ post infection we analysed the expression of cellular genes using
DNA microarray. We found that infection with $\mathrm{WSN}^{\mathrm{WT}}$ virus activated the expression of 33 genes more than eight-fold, whereas WSN ${ }^{\text {RK/AA }}$ virus induced expression of 88 genes over the same fold, including 31 transcripts that were the same as those upregulated by WSN ${ }^{\mathrm{WT}}$ (Fig. $2 \mathrm{~A}$ ). We validated our microarray results using RT-qPCR and ELISA (Fig. 2B and C). These results suggested that WSN virus via R38A and K41 residues of NS1 was able to down-regulate the transcription of antiviral genes in infected human RPE cells.

Importantly, we obtained similar results using human macrophages previously [31]. In particular, infection of human macrophages with $\mathrm{WSN}^{\mathrm{WT}}$ virus up-regulated the expression of 57 IFNs and ISGs more than eight-fold, whereas WSN ${ }^{\mathrm{RK} / \mathrm{AA}}$ virus infection activated the expression of 93 genes (>8-fold), including 32 of $\mathrm{WSN}^{\mathrm{WT}}$-up-regulated genes. These data suggested that WSN virus NS1 protein, via R38A and K41 residues was able to control the transcription of antiviral genes in both infected human macrophages and RPE cells. However, human macrophages derived from donors with different genetic and epigenetic background possessed slightly different responses to infection with WSN virus (Fig. S3) [29,31,45]. To exclude these variations, we used only RPE cells in our next experiments.

Gene set enrichment analysis showed that the majority of differentially expressed genes were involved in antiviral responses. To confirm this, we suppressed the expression of some of these genes using specific siRNAs before infection. We demonstrated that IFNB1, EIF2AK2 (PKR), IDO, BAMBI, CH25H, DDX60L, OAS1, OAS3, PTGS2 (COX2), and IFIH1 (MDA5) as well as TLR3 and MAVS (used as controls) were necessary
A

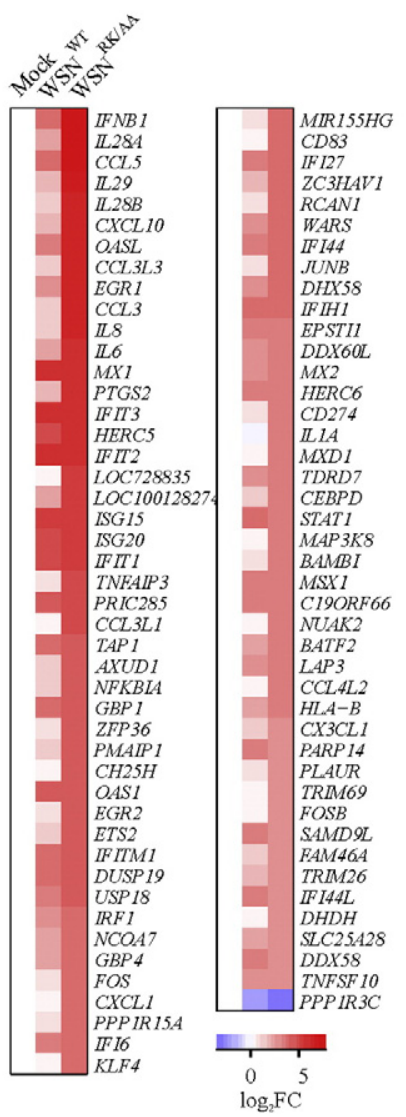

B

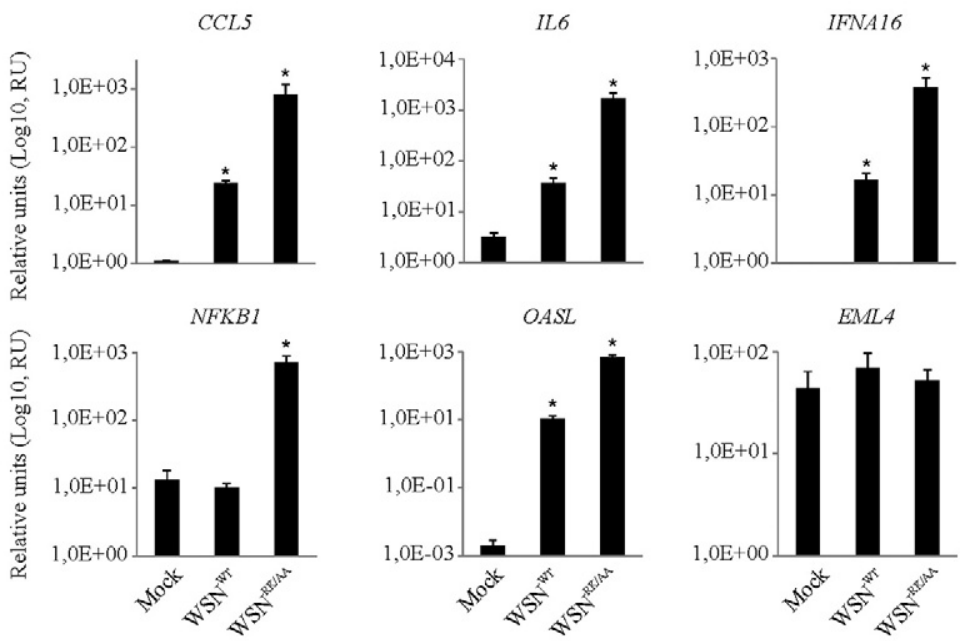

$\mathrm{E}$

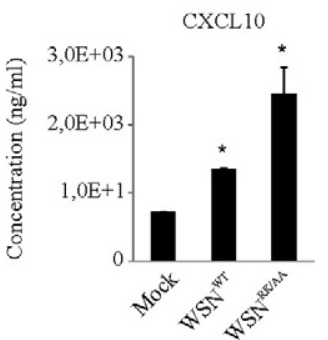

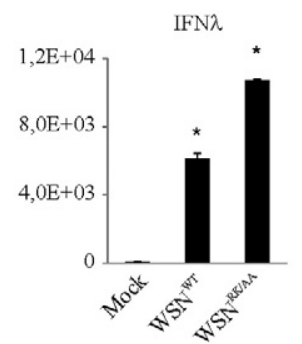

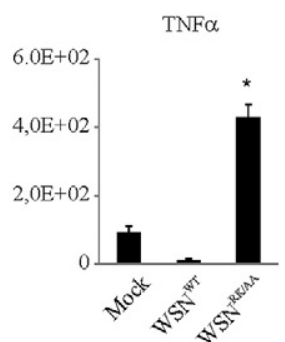

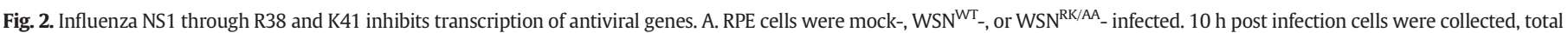

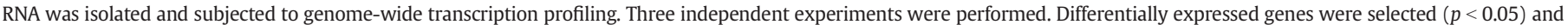

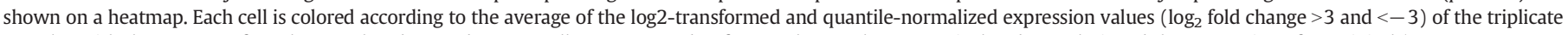

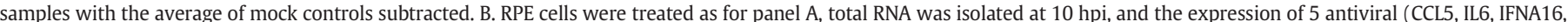

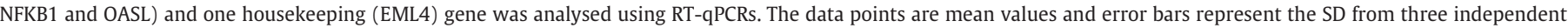

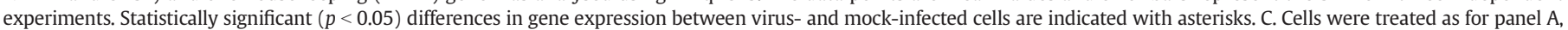
cell culture supernatants were collected at $24 \mathrm{~h}$ post-infection, and cytokine levels were determined using ELISA. 
to limit transcription and replication of viral M1 RNAs upon WSN ${ }^{\mathrm{WT}}$ and WSN ${ }^{\mathrm{RK} / \mathrm{AA}}$ virus infections (Fig. 3A). Interestingly, TLR3 but not TLR7 was required for transcription of IFNB1, which triggered the expression of a set of ISGs in response to IAV infection (Fig. 3B). Thus, IAV via R38 and K41 of NS1 attenuated transcription of antiviral IFNs and ISGs.

\subsection{NS1 locates to chromatin to suppress transcription of antiviral genes}

Next we asked how does NS1 control the transcription of antiviral genes. We first investigated the cellular localization of NS1 ${ }^{\mathrm{WT}}$ and $\mathrm{NS}^{\mathrm{RK} / \mathrm{AA}}$. We infected RPE cells with WSN ${ }^{\mathrm{WT}}$ or WSN ${ }^{\mathrm{RK} / \mathrm{AA}}$ viruses and after $10 \mathrm{~h}$ post infection examined the distribution of NS1 ${ }^{\mathrm{WT}}$ and $\mathrm{NS} 1^{\mathrm{RK} / \mathrm{AA}}$ by immunofluorescence. These experiments showed that both $\mathrm{NS} 1^{\mathrm{WT}}$ and $\mathrm{NS} 1^{\mathrm{RK} / \mathrm{AA}}$ were located mainly in the nucleus of infected cells (Fig. 4A).

We then purified NS1-associated factors from mock-, $\mathrm{WSN}^{\mathrm{WT}}$-, and $\mathrm{WSN}^{\mathrm{RK} / \mathrm{AA}}$-infected RPE cells. Cells were lysed with Triton X-100, and cell extracts were subjected to fractionations, high-RNAse A and highsalt treatments followed by SDS-PAGE, immunobloting, and agarose gel electrophoresis analysis. Surprisingly, the majority of NS1 ${ }^{\mathrm{WT}}$ and $\mathrm{NS} 1^{\mathrm{RK} / \mathrm{AA}}$ were found in insoluble fraction together with cellular DNA, RNA Pol II and histones (Fig. 4B). This indicates that NS1 can be copurified with chromatin factors from virus-infected cells.
We next extracted proteins from the insoluble fractions and analysed them by quantitative mass spectrometry (iTRAQ LC-MS/MS). We found that histones H3.2, H1.2, H1.5, H2A.1D and other chromatin-associated proteins were enriched in $\mathrm{NS}^{\mathrm{WT}}$ and $\mathrm{NS} 1^{\mathrm{RK} / \mathrm{AA}}$ containing insoluble fractions in comparison to mock (Fig. 4C; Table S2). Of note, some differences in the levels of H2A1D, YBOX-1, H3.2 and other proteins were seen between $\mathrm{NS}{ }^{\mathrm{WT}}$ - and NS1 ${ }^{\mathrm{RK} / \mathrm{AA}}$ containing fractions. These data suggest that $\mathrm{WSN}^{\mathrm{WT}}$ and $\mathrm{WSN}^{\mathrm{RK} / \mathrm{AA}}$ infections alter protein composition of chromatin fractions.

Next we investigated the consequences of the altered histone composition on NS1 interaction with specific gene regions during IAV infection. For this, RPE cells were mock-infected or infected with either $\mathrm{WSN}^{\mathrm{WT}}$ or WSN ${ }^{\mathrm{RK} / \mathrm{AA}}$ viruses for $8 \mathrm{~h}$. NS1- and Pol II-associated DNA was extracted from chromatin fractions of infected and non-infected cells. The promoter and exon regions of IFNB1 were analysed using q-PCR. We found that NS1 ${ }^{\mathrm{WT}}$ was enriched on the promoter and exon region of IFNB1 in WSN ${ }^{\mathrm{WT}}$ infected cells, whereas Pol II was enriched on the same IFNB1 regions in WSN $\mathrm{NK}^{\mathrm{RK}}$ infected cells (Fig. 4D). These results suggest that wild type NS1 can prevent the association of Pol II with IFNB1 gene during virus infection. Altogether, these results may indicate that upon IAV infection PRRs mediated chromatin remodelling to activate the expression of antiviral genes and suppress general transcription, and NS1 upon expression suppresses transcription of some antiviral genes, depending on chromatin context.
A
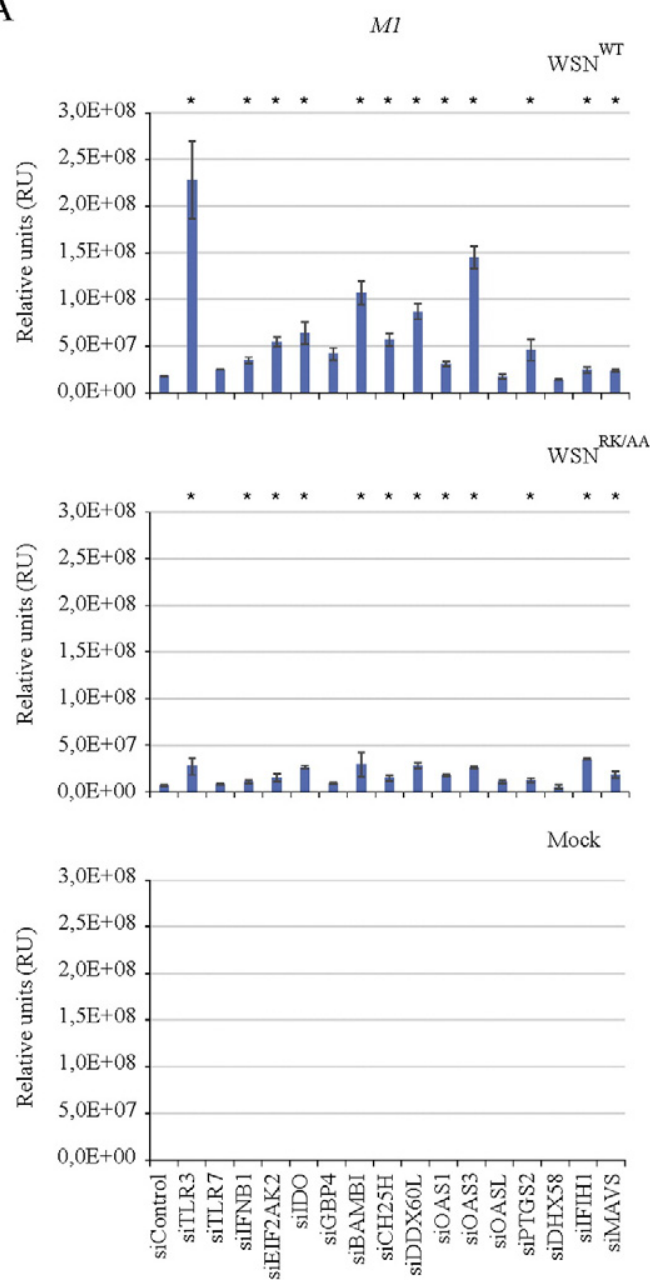

B
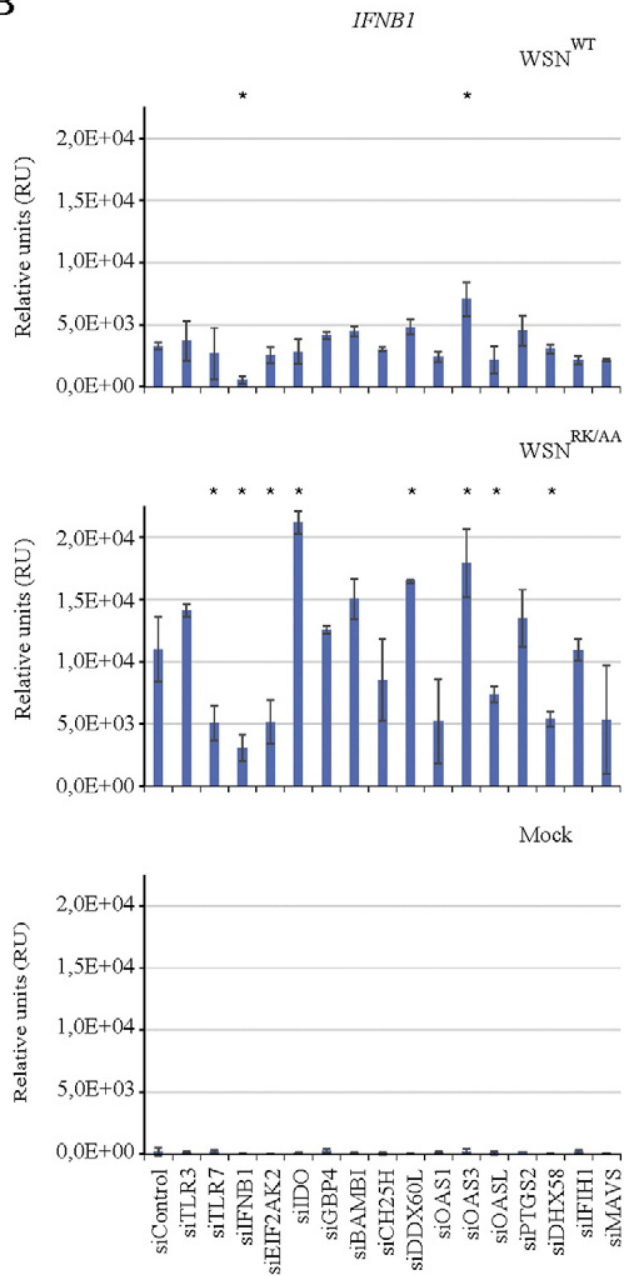

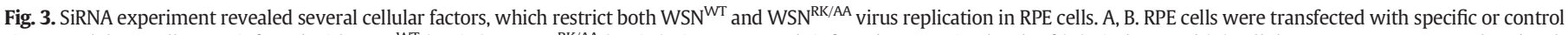

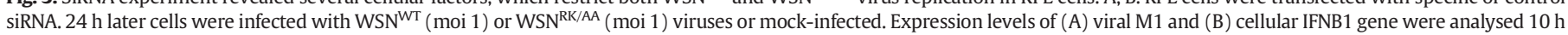
later by RT-qPCRs. Statistically significant $(p<0.05)$ differences in gene expression between non-targeted siRNA control and targeted siRNA condition are indicated with asterisks. 
A

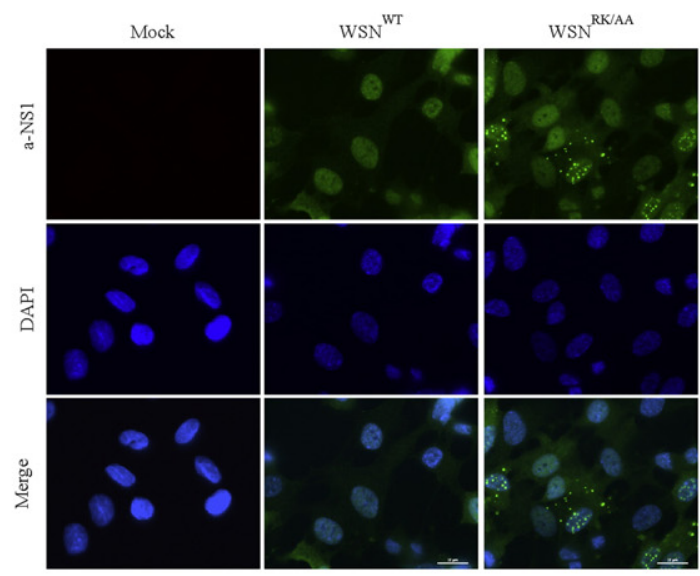

B
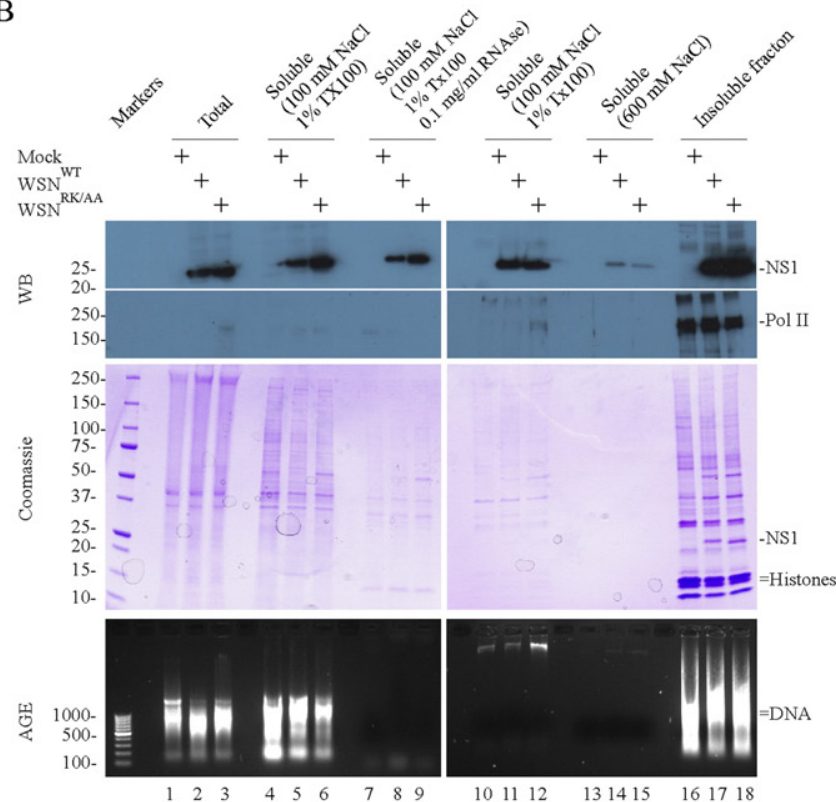

$\mathrm{C}$
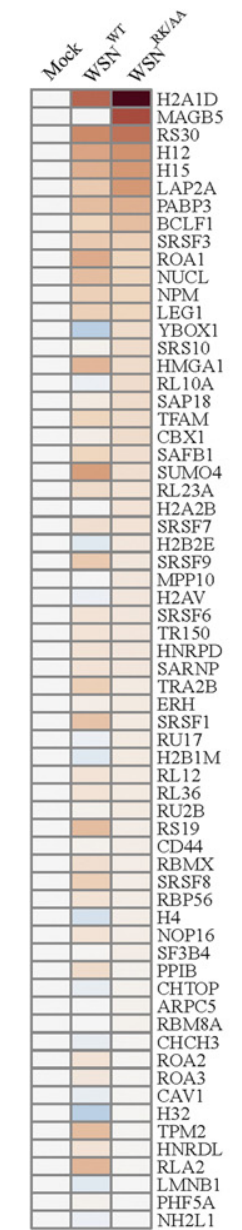

$\mathrm{D}$

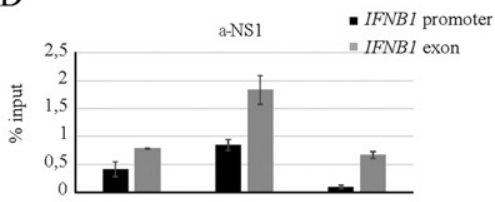

a-Pol II

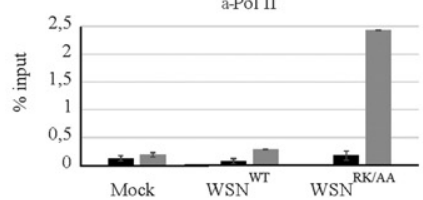

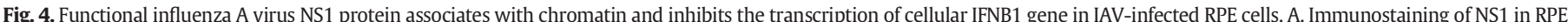

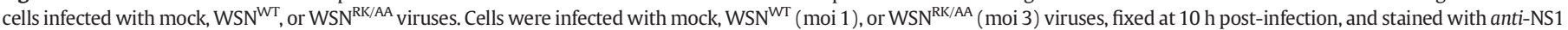

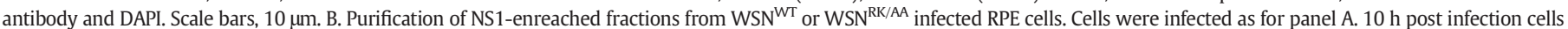

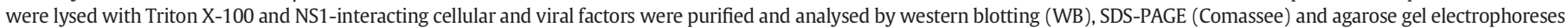

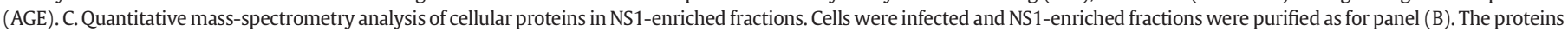

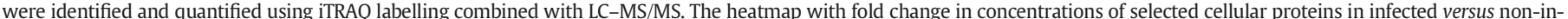

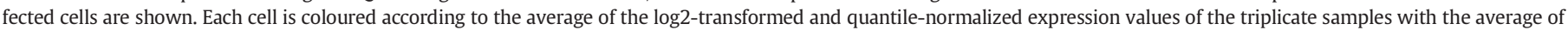

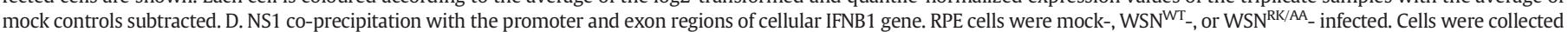

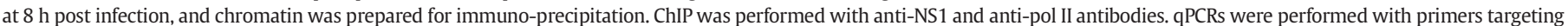

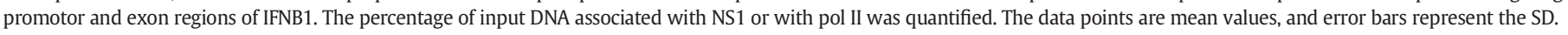

\subsection{Purified recombinant NS1 through R38 and K41 binds synthetic dsDNA and inhibits Pol II transcription in vitro}

To further analyse the mechanisms of NS1 binding to DNA, we performed EMSA experiment with purified NS1 ${ }^{\mathrm{WT}}$ and NS1 ${ }^{\mathrm{RK} / \mathrm{AA}}$ proteins (Fig. 5A). For this experiment, we produced linear synthetic dsDNA (DNA-SELEX), which contained central random $16 \mathrm{~N}$ base pair (bp) region flanked by defined 30 bp sequences. $16 \mathrm{~N}$ bp region was chosen because NS1 RBD dimer was shown to occupy 16 bp of A-form dsRNA [46]. EMSA showed that NS1 ${ }^{\mathrm{WT}}$ but not NS1 ${ }^{\mathrm{RK} / \mathrm{AA}}$ retarded the migration of dsDNA in EMSA analysis (Fig. 5B). We analysed the possible sequence-specificity of NS1 interaction with its target DNA using Sanger sequencing, i.e. we sequenced NS1interacting DNA. We found that NS1 bind DNA independently of 
A

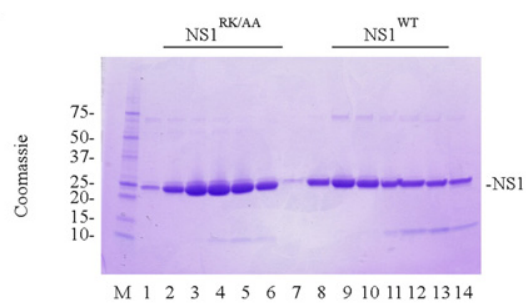

C

5'-GTTCAGAGTTCTACAGT CCGAGGATCTGG [ $\left.\mathrm{N}_{16}\right]$ CC AGCTGTCGTATGCCGTCTTC TGCTTG-3' 3'-CAAGACTCAAGATGTCACCTCCTAGACC [N $\mathrm{N}_{16}$ ] GG TCGACAGCATACGGCAGAAG AC \&AAC-5'

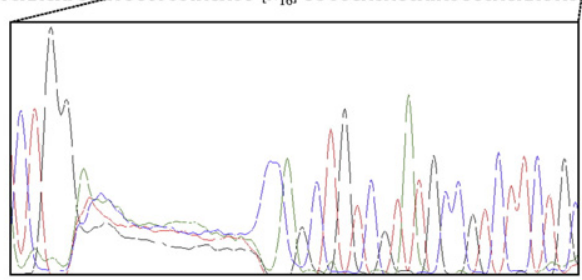

E

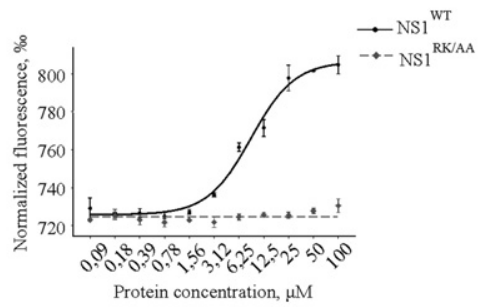

G

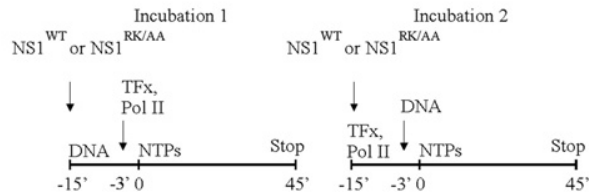

B

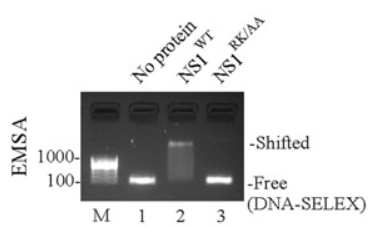

D

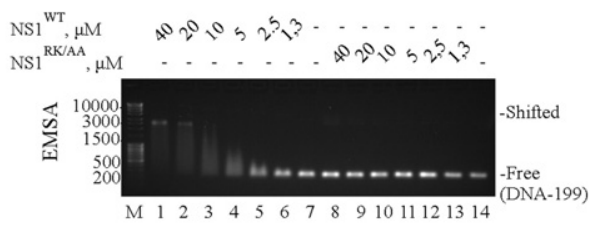

F

$\mathrm{NSI}^{\mathrm{WT}}, \mu \mathrm{M}-0,0 \times 0.0 \%-\cdots$

$\mathrm{NS} 1^{\mathrm{RK} / \mathrm{AA}}, \mu \mathrm{M}$ - . - . $200.0 \% 0 \%$

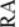

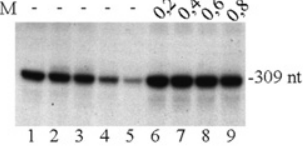

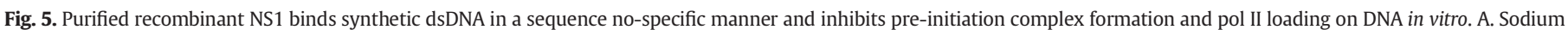

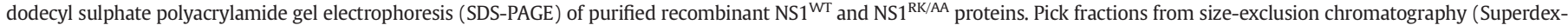

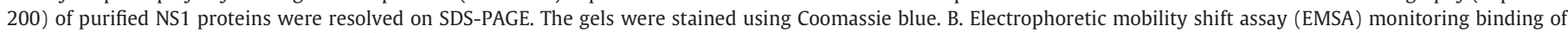

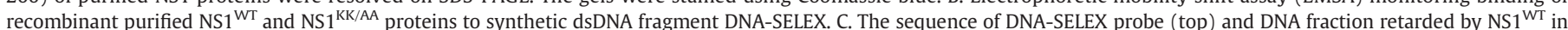

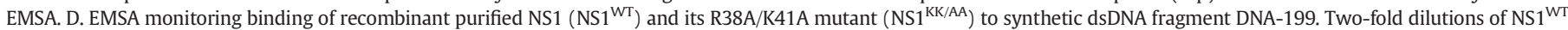

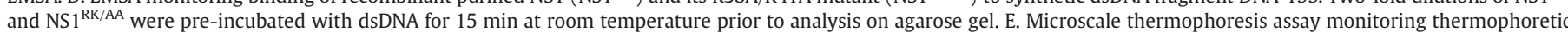

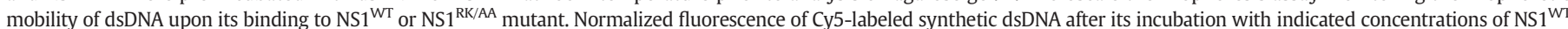

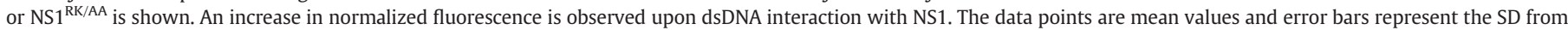

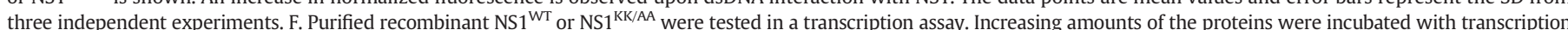

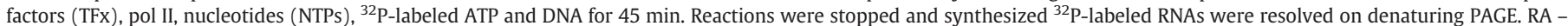

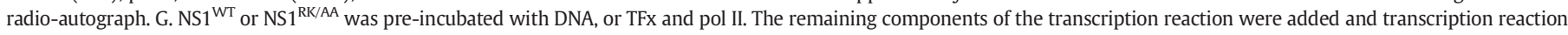

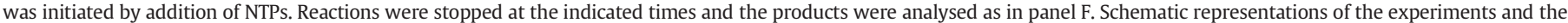
autoradiographs (RA) are shown.

sequence of central region, suggesting that the interaction was not sequence-specific (Fig. 5C).

We then determined the dissociation constant $\left(\mathrm{K}_{\mathrm{d}}\right)$ of $\mathrm{NS} 1^{\mathrm{WT}}$ and dsDNA fragment (DNA-199). EMSA showed that NS1 ${ }^{\text {WT }}$ retarded the migration of DNA-199 probe in a concentration-dependent manner with micromolar $K_{d}$ (Fig. 5D). Microscale thermophoresis assay revealed that the $K_{d}$ for $\mathrm{NS}_{1}{ }^{\mathrm{WT}}$ was $11.1 \pm 0.7 \mu \mathrm{M}$, whereas the $\mathrm{K}_{\mathrm{d}}$ for $\mathrm{NS}^{\mathrm{RK} / \mathrm{AA}}$ was $>100 \mu \mathrm{M}$ (Fig. $5 \mathrm{E}$ ). Interestingly, the $\mathrm{K}_{\mathrm{d}}$ for $\mathrm{NS} 1^{\mathrm{WT}}$ dsDNA complex was comparable to that of $\mathrm{NS}^{\mathrm{WT}}$-dsRNA complex reported previously [39,46-48]. These results suggested that in vitro NS1 binds dsDNA non-specifically with micromolar affinity, and that the residues R38 and K41 of NS1 are essential for the binding.

To address whether NS1 through R38 and K41 can inhibit transcription in vitro, we purified recombinant $\mathrm{NS} 1^{\mathrm{WT}}$ or $\mathrm{NS} 1^{\mathrm{RK} / \mathrm{AA}}$ proteins (Fig. 4A) and added them to in vitro run-off transcription assays containing naked AdMLP DNA template. We found that NS1 ${ }^{\text {WT }}$ but not NS1 ${ }^{\mathrm{RK} / \mathrm{AA}}$ inhibited the in vitro synthesis of RNA in a concentration-dependent manner (Fig. 4F). To further understand how NS1 was able to block transcription, we set up two different experimental conditions. We first pre-incubated NS1 with dsDNA, and then added pre-initiation complex (PIC) and Pol II before the reaction started (Fig. 4G, incubation 1). Alternatively, we pre-incubated NS1 with PIC and Pol II, and then added dsDNA (Fig. 4G, incubation 2). In both experimental settings, $\mathrm{NS} 1^{\mathrm{WT}}$ but not NS1 ${ }^{\mathrm{RK} / \mathrm{AA}}$ inhibited the in vitro RNA synthesis. We concluded that NS1 inhibits in vitro transcription by binding to DNA, which prevents the loading of PIC and Pol II.

\section{Discussion}

Influenza NS1 protein is an important virulence factor and deciphering the mechanism by which NS1 antagonizes antiviral responses is critical for understanding of disease progression. Here we 
demonstrated that influenza NS1 binds synthetic dsDNA in a sequence non-specific manner. Furthermore, we showed that this interaction inhibited the loading of transcriptional machinery on the synthetic DNA and thereby prevented the transcription reaction in vitro. In infected cells, NS1 inhibited Pol II recruitment to the exon and promoter regions of IFNB1. This observation could be potentially expanded to other IFN genes and ISGs whose transcription was up-regulated in response to $\mathrm{WSN}^{\mathrm{RK} / \mathrm{AA}}$ in comparison to WSN ${ }^{\mathrm{WT}}$ and mock infections. In addition, our results indicate that IAV infection promoted chromatin remodelling, which could be associated with inhibition of general transcription and activation of expression of certain IFNs and ISGs. Influenza NS1 protein could, therefore, bind DNA of transcriptionally active genes and attenuate their expression. This may potentially lead to reduced expression of IFNs and ISGs, leading to compromised antiviral responses of infected cells.

Importantly, R38 and K41 residues of NS1 mediate an interaction of IAV NS1 with non-specific dsDNA and dsRNA, and the dissociation constants of these interactions are very similar [39,46-48]. This suggests that NS1 can bind both dsDNA/RNA via the phosphate backbone. Binding of NS1 to dsDNA/RNA can hinder them from loading of cellular transcription machinery and recognition by cellular PRRs, respectively.

Interestingly, our attempt to purify NS1 from infected cells revealed that the majority of NS1 was in insoluble fraction together with histones, transcription machinery and DNA. High salt and RNAse treatments of these fraction, as well as R38A and K41A mutations in NS1, did not increase NS1 solubility. This indicates that additional transcriptional regulation mechanisms involving NS1 interactions with cellular factors may take place, which is in agreement with previous findings showing that NS1 non-conserved residues outside dsDNA/RNA binding site may interact with chromatin-associated factors [49,50].

The RNA/DNA-binding residues R38 and K41 of NS1 protein are evolutionary conserved among IAVs. Moreover, the corresponding NS1 residues are also conserved in influenza B viruses [51-53]. Thus, our findings point to a general strategy, by which influenza viruses can antagonize antiviral responses in infected cells to secure its replications. Other RNA viruses are also able to inhibit cellular transcription to secure their replication. For example, bunyamwera virus NS-S protein inhibits the phosphorylation of Pol II C-terminal domain, while Rift Valley Fever Virus NSs protein targets TFIIH to inhibit the transcription of cellular genes including those of antiviral genes [54,55]. However, to our knowledge, there are no data available except this study, that negative- or positive-sense RNA viruses can inhibit cellular transcription by direct binding of viral proteins to cellular DNA. Thus, our work provides a first example of such a mechanism that could be potentially exploited by other RNA virus families.

Finally, the influenza NS1-dsDNA interaction can be potentially exploited for treatment of IAV infection. In particular, small-molecular inhibitors of this interaction can potentially restore innate immune responses and inhibit virus replication. In addition, viruses expressing dsDNA binding deficient NS1 may display characteristics desirable for potential live-attenuated viral vaccines.

\section{Conclusions}

Host cell activates transcription of a set of antiviral genes in response to IAV infection. Our results suggest that the viral NS1 protein can inhibit transcription of some of these genes by binding to dsDNA and preventing the loading of cellular transcription machinery. Thus, IAV can exploit its NS1 protein to attenuate antiviral responses at transcriptional level to secure its replication.

\section{Transparency document}

The Transparency document associated with this article can be found, in online version.

\section{Acknowledgments}

We thank Dr. Robert G. Webster for WSN reverse-genetics. This work was supported by University of Helsinki three-year research project grant (465/51/2014 to DEK), Jane and Aatos Erkko, Sigrid Juselius and Finnish Cultural foundations, the Academy of Finland (grant no 252252 to DEK and IJ, and 256159, 255780, 135628. and 255842 to I.J.), European Molecular Biology Organization short-term fellowship and Helsinki Biomedical Graduate School scholarship (to MA).

\section{Appendix A. Supplementary data}

Supplementary data to this article can be found online at http://dx. doi.org/10.1016/j.bbagrm.2016.09.005.

\section{References}

[1] GBD 2013, Mortality and Causes of Death Collaborators. Global, regional, and national age-sex specific all-cause and cause-specific mortality for 240 causes of death, 1990-2013: a systematic analysis for the global burden of disease study 2013, Lancet 385 (9963) (2015) 117-171, http://dx.doi.org/10.1016/S0140-6736(14)61682-2 (PubMed PMID: 25530442; PubMed Central PMCID: PMCPMC4340604).

[2] A. Iwasaki, P.S. Pillai, Innate immunity to influenza virus infection, Nat. Rev. Immunol. 14 (5) (2014) 315-328, http://dx.doi.org/10.1038/nri3665 (PubMed PMID: 24762827; PubMed Central PMCID: PMCPMC4104278).

[3] M.J. Ciancanelli, S.X. Huang, P. Luthra, H. Garner, Y. Itan, S. Volpi, et al., Infectious disease. Life-threatening influenza and impaired interferon amplification in human IRF7 deficiency, Science 348 (6233) (2015) 448-453, http://dx.doi.org/10. 1126/science.aaa1578 (PubMed PMID: 25814066; PubMed Central PMCID: PMCPMC4431581).

[4] P.S. Pillai, R.D. Molony, K. Martinod, H. Dong, I.K. Pang, M.C. Tal, et al., Mx1 reveals innate pathways to antiviral resistance and lethal influenza disease, Science 352 (6284) (2016) 463-466, http://dx.doi.org/10.1126/science.aaf3926 (PubMed PMID: 27102485).

[5] M. Miettinen, T. Sareneva, I. Julkunen, S. Matikainen, IFNs activate toll-like receptor gene expression in viral infections, Genes Immun. 2 (6) (2001) 349-355, http://dx. doi.org/10.1038/sj.gene.6363791 (PubMed PMID: 11607792).

[6] S.M. Makela, P. Osterlund, V. Westenius, S. Latvala, M.S. Diamond, M. Gale Jr., et al., RIG-I signaling is essential for influenza B virus-induced rapid interferon gene expression, J. Virol. 89 (23) (2015) 12014-12025, http://dx.doi.org/10.1128/JVI. 01576-15 (PubMed PMID: 26378160; PubMed Central PMCID: PMCPMC4645339).

[7] A.G. Bowie, L. Unterholzner, Viral evasion and subversion of pattern-recognition receptor signalling, Nat. Rev. Immunol. 8 (12) (2008) 911-922, http://dx.doi.org/10. 1038/nri2436 (PubMed PMID: 18989317).

[8] S.Y. Liu, D.J. Sanchez, R. Aliyari, S. Lu, G. Cheng, Systematic identification of type I and type II interferon-induced antiviral factors, Proc. Natl. Acad. Sci. U. S. A. 109 (11) (2012) 4239-4244, http://dx.doi.org/10.1073/pnas.1114981109 (PubMed PMID: 22371602; PubMed Central PMCID: PMCPMC3306696).

[9] J.W. Schoggins, S.J. Wilson, M. Panis, M.Y. Murphy, C.T. Jones, P. Bieniasz, et al., A diverse range of gene products are effectors of the type I interferon antiviral response, Nature 472 (7344) (2011) 481-485, http://dx.doi.org/10.1038/nature09907 (PubMed PMID: 21478870; PubMed Central PMCID: PMCPMC3409588).

[10] H.M. Lazear, T.J. Nice, M.S. Diamond, Interferon-lambda: immune functions at barrier surfaces and beyond, Immunity 43 (1) (2015) 15-28, http://dx.doi.org/10. 1016/j.immuni.2015.07.001 (PubMed PMID: 26200010; PubMed Central PMCID: PMCPMC4527169).

[11] D. Goubau, M. Schlee, S. Deddouche, A.J. Pruijssers, T. Zillinger, M. Goldeck, et al., Antiviral immunity via RIG-I-mediated recognition of RNA bearing 5'-diphosphates, Nature 514 (7522) (2014) 372-375, http://dx.doi.org/10.1038/nature13590 (PubMed PMID: 25119032; PubMed Central PMCID: PMCPMC4201573).

[12] A.A. Benitez, M. Panis, J. Xue, A. Varble, J.V. Shim, A.L. Frick, et al., In vivo RNAi screening identifies MDA5 as a significant contributor to the cellular defense against influenza A virus, Cell Rep. 11 (11) (2015) 1714-1726, http://dx.doi.org/ 10.1016/j.celrep.2015.05.032 (PubMed PMID: 26074083; PubMed Central PMCID: PMCPMC4586153).

[13] A.M. Pham, F.G. Santa Maria, T. Lahiri, E. Friedman, I.J. Marie, D.E. Levy, PKR transduces MDA5-dependent signals for type I IFN induction, PLoS Pathog. 12 (3) (2016), e1005489 http://dx.doi.org/10.1371/journal.ppat.1005489 (PubMed PMID: 26939124; PubMed Central PMCID: PMCPMC4777437).

[14] J. Melchjorsen, H. Kristiansen, R. Christiansen, J. Rintahaka, S. Matikainen, S.R. Paludan, et al., Differential regulation of the OASL and OAS1 genes in response to viral infections, J. Interf. Cytokine Res. 29 (4) (2009) 199-207, http://dx.doi.org/ 10.1089/jir.2008.0050 (PubMed PMID: 19203244).

[15] J.Y. Min, R.M. Krug, The primary function of RNA binding by the influenza A virus NS1 protein in infected cells: inhibiting the $2^{\prime}-5^{\prime}$ oligo (A) synthetase/RNase L pathway, Proc. Natl. Acad. Sci. U. S. A. 103 (18) (2006) 7100-7105, http://dx.doi.org/10. 1073/pnas.0602184103 (PubMed PMID: 16627618; PubMed Central PMCID: PMC1459024).

[16] U.Y. Choi, J.S. Kang, Y.S. Hwang, Y.J. Kim, Oligoadenylate synthase-like (OASL) proteins: dual functions and associations with diseases, Exp. Mol. Med. 47 (2015), 
e144 http://dx.doi.org/10.1038/emm.2014.110 (PubMed PMID: 25744296; PubMed Central PMCID: PMCPMC4351405).

[17] M. Moriyama, I.Y. Chen, A. Kawaguchi, T. Koshiba, K. Nagata, H. Takeyama, et al., The RNA- and TRIM25-binding domains of influenza virus NS1 protein are essential for suppression of NLRP3 inflammasome-mediated interleukin-1beta secretion, J. Virol. 90 (8) (2016) 4105-4114, http://dx.doi.org/10.1128/JVI.00120-16 (PubMed PMID: 26865721; PubMed Central PMCID: PMCPMC4810543).

[18] S. Ludwig, T. Wolff, Influenza A virus TRIMs the type I interferon response, Cell Host Microbe 5 (5) (2009) 420-421, http://dx.doi.org/10.1016/j.chom.2009.05.004 (PubMed PMID: 19454344).

[19] E.S. Gold, A.H. Diercks, I. Podolsky, R.L. Podyminogin, P.S. Askovich, P.M. Treuting, et al., 25-Hydroxycholesterol acts as an amplifier of inflammatory signaling, Proc. Natl. Acad. Sci. U. S. A. 111 (29) (2014) 10666-10671, http://dx. doi.org/10.1073/pnas.1404271111 (PubMed PMID: 24994901; PubMed Central PMCID: PMCPMC4115544).

[20] D. Pilla-Moffett, M.F. Barber, G.A. Taylor, J. Coers, Interferon-inducible GTPases in host resistance, Inflamm. Dis. J. Mol. Biol. (2016) http://dx.doi.org/10.1016/j.jmb. 2016.04.032 (PubMed PMID: 27181197).

[21] E. Meunier, P. Broz, Interferon-inducible GTPases in cell autonomous and innate immunity, Cell. Microbiol. 18 (2) (2016) 168-180, http://dx.doi.org/10.1111/cmi. 12546 (PubMed PMID: 26572694).

[22] B.H. Kim, A.R. Shenoy, P. Kumar, C.J. Bradfield, J.D. MacMicking, IFN-inducible GTPases in host cell defense, Cell Host Microbe 12 (4) (2012) 432-444, http://dx. doi.org/10.1016/j.chom.2012.09.007 (PubMed PMID: 23084913; PubMed Central PMCID: PMCPMC3490204).

[23] S.E. Dudek, K. Nitzsche, S. Ludwig, E. C., Influenza A viruses suppress cyclooxygenase-2 expression by affecting its mRNA stability, Sci. Rep. 6 (2016), 27275 http://dx.doi.org/10.1038/srep27275 (PubMed PMID: 27265729; PubMed Central PMCID: PMCPMC4893666).

[24] L. Huang, R. Ou, G. Rabelo de Souza, C. TM, H. Lemos, E. Mohamed, et al., Virus infections incite pain hypersensitivity by inducing indoleamine 2,3 dioxygenase, PLoS Pathog. 12 (5) (2016), e1005615 http://dx.doi.org/10.1371/journal.ppat.1005615 (PubMed PMID: 27168185; PubMed Central PMCID: PMCPMC4863962).

[25] J.M. Fox, J.M. Crabtree, L.K. Sage, S.M. Tompkins, R.A. Tripp, Interferon lambda upregulates IDO1 expression in respiratory epithelial cells after influenza virus infection, J. Interf. Cytokine Res. 35 (7) (2015) 554-562, http://dx.doi.org/ 10.1089/jir.2014.0052 (PubMed PMID: 25756191; PubMed Central PMCID: PMCPMC4507134).

[26] Z.A. Bornholdt, B.V. Prasad, X-ray structure of NS1 from a highly pathogenic H5N1 influenza virus, Nature 456 (7224) (2008) 985-988, http://dx.doi.org/10.1038/ nature07444 (PubMed PMID: 18987632; PubMed Central PMCID: PMC2798118).

[27] J. Ayllon, A. Garcia-Sastre, The NS1 protein: a multitasking virulence factor, Curr. Top. Microbiol. Immunol. 386 (2015) 73-107, http://dx.doi.org/10.1007/82_ 2014_400 (PubMed PMID: 25007846).

[28] Z. Zhu, Z. Shi, W. Yan, J. Wei, D. Shao, X. Deng, et al., Nonstructural protein 1 of influenza A virus interacts with human guanylate-binding protein 1 to antagonize antiviral activity, PLoS ONE 8 (2) (2013), e55920 http://dx.doi.org/10.1371 journal.pone.0055920 (PubMed PMID: 23405236; PubMed Central PMCID: PMCPMC3566120).

[29] M. Anastasina, B. Schepens, S. Soderholm, T.A. Nyman, S. Matikainen, K. Saksela, et al., The C terminus of NS1 protein of influenza A/WSN/1933(H1N1) virus modulates antiviral responses in infected human macrophages and mice, J. Gen. Virol. 96 (8) (2015) 2086-2091, http://dx.doi.org/10.1099/vir.0.000171 (PubMed PMID: 25934792).

[30] I. Marazzi, J.S. Ho, J. Kim, B. Manicassamy, S. Dewell, R.A. Albrecht, et al., Suppression of the antiviral response by an influenza histone mimic, Nature 483 (7390) (2012) 428-433, http://dx.doi.org/10.1038/nature10892 (PubMed PMID: 22419161; PubMed Central PMCID: PMC3598589).

[31] S. Soderholm, M. Anastasina, M.M. Islam, J. Tynell, M.M. Poranen, D.H. Bamford, et al., Immuno-modulating properties of saliphenylhalamide, SNS-032, obatoclax, and gemcitabine, Antivir. Res. 126 (2016) 69-80, http://dx.doi.org/10.1016/j. antiviral.2015.12.011 (PubMed PMID: 26738783).

[32] O.V. Denisova, L. Kakkola, L. Feng, J. Stenman, A. Nagaraj, J. Lampe, et al., Obatoclax, saliphenylhalamide, and gemcitabine inhibit influenza a virus infection, J. Biol. Chem. 287 (42) (2012) 35324-35332, http://dx.doi.org/10.1074/jbc.M112.392142 (PubMed PMID: 22910914; PubMed Central PMCID: PMCPMC3471742)

[33] A.H. Broquet, Y. Hirata, C.S. McAllister, M.F. Kagnoff, RIG-I/MDA5/MAVS are required to signal a protective IFN response in rotavirus-infected intestinal epithelium, J. Immunol. 186 (3) (2011) 1618-1626, http://dx.doi.org/10.4049/jimmunol. 1002862 (PubMed PMID: 21187438).

[34] L. Slater, N.W. Bartlett, J.J. Haas, J. Zhu, S.D. Message, R.P. Walton, et al., Co-ordinated role of TLR3, RIG-I and MDA5 in the innate response to rhinovirus in bronchial epithelium, PLoS Pathog. 6 (11) (2010), e1001178 http://dx.doi.org/10.1371/ journal.ppat.1001178 (PubMed PMID: 21079690; PubMed Central PMCID: PMCPMC2973831)

[35] O.V. Denisova, S. Soderholm, S. Virtanen, C. Von Schantz, D. Bychkov, E. Vashchinkina, et al., Akt inhibitor MK2206 prevents influenza pH1N1 virus infection in vitro, Antimicrob. Agents Chemother. 58 (7) (2014) 3689-3696, http://dx.doi. org/10.1128/AAC.02798-13 (PubMed PMID: 24752266; PubMed Central PMCID: PMCPMC4068572)

[36] T. Ohman, N. Lietzen, E. Valimaki, J. Melchjorsen, S. Matikainen, T.A. Nyman, Cytosolic RNA recognition pathway activates $14-3-3$ protein mediated signaling and caspase-dependent disruption of cytokeratin network in human keratinocytes, J. Proteome Res. 9 (3) (2010) 1549-1564, http://dx.doi.org/10.1021/pr901040u (PubMed PMID: 20070120).

37] L. Kakkola, O.V. Denisova, J. Tynell, J. Viiliainen, T. Ysenbaert, R.C. Matos, et al. Anticancer compound ABT-263 accelerates apoptosis in virus-infected cells and imbalances cytokine production and lowers survival rates of infected mice, Cell Death Dis. 4 (2013), e742 http://dx.doi.org/10.1038/cddis.2013.267 (PubMed PMID: 23887633; PubMed Central PMCID: PMC3730437).

[38] N. Lietzen, T. Ohman, J. Rintahaka, I. Julkunen, T. Aittokallio, S. Matikainen, et al. Quantitative subcellular proteome and secretome profiling of influenza A virusinfected human primary macrophages, PLoS Pathog. 7 (5) (2011), e1001340 http://dx.doi.org/10.1371/journal.ppat.1001340 (PubMed PMID: 21589892; PubMed Central PMCID: PMCPMC3093355).

[39] D.E. Kainov, K.H. Muller, L.L. Theisen, M. Anastasina, M. Kaloinen, C.P. Muller, Differential effects of NS1 proteins of human pandemic H1N1/2009, avian highly pathogenic H5N1, and low pathogenic H5N2 influenza A viruses on cellular pre-mRNA polyadenylation and mRNA translation, J. Biol. Chem. 286 (9) (2011) 7239-7247, http://dx.doi.org/10.1074/jbc.M110.203489 (PubMed PMID: 21163951; PubMed Central PMCID: PMCPMC3044980)

[40] M. Gerard, L. Fischer, V. Moncollin, J.M. Chipoulet, P. Chambon, J.M. Egly, Purification and interaction properties of the human RNA polymerase B(II) general transcription factor BTF2, J. Biol. Chem. 266 (31) (1991) 20940-20945 (PubMed PMID: 1939143).

[41] D.E. Kainov, L.A. Selth, J.Q. Svejstrup, J.M. Egly, A. Poterzsman, Interacting partners of the Tfb2 subunit from yeast TFIIH, DNA Repair (Amst) 9 (1) (2010) 33-39, http:// dx.doi.org/10.1016/j.dnarep.2009.10.002 (PubMed PMID: 19897425).

[42] T.R. Riley, M. Slattery, N. Abe, C. Rastogi, D. Liu, R.S. Mann, et al., SELEX-seq: a method for characterizing the complete repertoire of binding site preferences for transcription factor complexes, Methods Mol. Biol. 1196 (2014) 255-278, http:// dx.doi.org/10.1007/978-1-4939-1242-1_16 (PubMed PMID: 25151169; PubMed Central PMCID: PMCPMC4265583).

[43] N.R. Donelan, C.F. Basler, A. Garcia-Sastre, A recombinant influenza A virus expressing an RNA-binding-defective NS1 protein induces high levels of beta interferon and is attenuated in mice, J. Virol. 77 (24) (2003) 13257-13266 (PubMed PMID: 14645582; PubMed Central PMCID: PMC296096).

[44] C.M. Newby, L. Sabin, A. Pekosz, The RNA binding domain of influenza A virus NS1 protein affects secretion of tumor necrosis factor alpha, interleukin-6, and interferon in primary murine tracheal epithelial cells, J. Virol. 81 (17) (2007) 9469-9480, http://dx.doi.org/10.1128/JVI.00989-07 (PubMed PMID: 17596305; PubMed Central PMCID: PMC1951395).

[45] Y. Fu, L. Gaelings, S. Söderholm, S. Belanov, J. Nandania, T.A. Nyman, et al., JNJ872 inhibits influenza A virus replication without altering cellular antiviral responses, Antivir. Res. (2016) http://dx.doi.org/10.1016/j.antiviral.2016.07.008 (in press).

[46] A. Cheng, S.M. Wong, Y.A. Yuan, Structural basis for dsRNA recognition by NS1 protein of influenza A virus, Cell Res. 19 (2) (2009) 187-195, http://dx.doi.org/10. 1038/cr.2008.288 (PubMed PMID: 18813227).

[47] W. Wang, K. Riedel, P. Lynch, C.Y. Chien, G.T. Montelione, R.M. Krug, RNA binding by the novel helical domain of the influenza virus NS1 protein requires its dimer structure and a small number of specific basic amino acids, RNA 5 (2) (1999) 195-205 (PubMed PMID: 10024172; PubMed Central PMCID: PMC1369752).

[48] C.Y. Chien, Y. Xu, R. Xiao, J.M. Aramini, P.V. Sahasrabudhe, R.M. Krug, et al., Biophysical characterization of the complex between double-stranded RNA and the Nterminal domain of the NS1 protein from influenza A virus: evidence for a novel RNA-binding mode, Biochemistry 43 (7) (2004) 1950-1962, http://dx.doi.org/10. 1021/bi030176o (PubMed PMID: 14967035)

[49] S.N. Thulasi Raman, Y.Zhou, Networks of host factors that interact with NS1 protein of influenza A virus, Front. Microbiol. 7 (2016) 654, http://dx.doi.org/10.3389/fmicb. 2016.00654 (PubMed PMID: 27199973; PubMed Central PMCID: PMCPMC4855030).

[50] S. Qin, Y. Liu, W. Tempel, M.S. Eram, C. Bian, K. Liu, et al., Structural basis for histone mimicry and hijacking of host proteins by influenza virus protein NS1, Nat. Commun. 5 (2014) 3952, http://dx.doi.org/10.1038/ncomms4952 (PubMed PMID: 24853335).

[51] C. Yin, J.A. Khan, G.V. Swapna, A. Ertekin, R.M. Krug, L. Tong, et al., Conserved surface features form the double-stranded RNA binding site of non-structural protein 1 (NS1) from influenza A and B viruses, J. Biol. Chem. 282 (28) (2007) 20584-20592. http://dx.doi.org/10.1074/jbc.M611619200 (PubMed PMID: 17475623).

[52] B. Dauber, J. Schneider, W. T., Double-stranded RNA binding of influenza B virus nonstructural NS1 protein inhibits protein kinase R but is not essential to antagonize production of alpha/beta interferon, J. Virol. 80 (23) (2006) 11667-11677, http://dx.doi.org/10.1128/JVI.01142-06 (PubMed PMID: 16987984; PubMed Central PMCID: PMCPMC1642593).

[53] W. Wang, R.M. Krug, The RNA-binding and effector domains of the viral NS1 protein are conserved to different extents among influenza A and B viruses, Virology 223 (1) (1996) 41-50, http://dx.doi.org/10.1006/viro.1996.0453 (PubMed PMID: 8806538)

[54] N. Le May, S. Dubaele, P. De Santis L, A. Billecocq, M. Bouloy, E. JM, TFIIH transcription factor, a target for the Rift Valley hemorrhagic fever virus, Cell 116 (4) (2004) 541-550 (PubMed PMID: 14980221)

[55] D. Thomas, G. Blakqori, V. Wagner, M. Banholzer, N. Kessler, R.M. Elliott, et al., Inhibition of RNA polymerase II phosphorylation by a viral interferon antagonist, J. Biol. Chem. 279 (30) (2004) 31471-31477, http://dx.doi.org/10.1074/jbc.M400938200 (PubMed PMID: 15150262). 